\title{
ANGKA PALING MUNGKIN DAN DETEKSI COLIFORM PADA SAMPEL LALAPAN DAUN KEMANGI (Ocimum bacilicum) DI KOTA PONTIANAK
}

\author{
Ita Purnama Sari ${ }^{1}$, Rahmawati ${ }^{1}$, Rikhsan Kurniatuhadi ${ }^{1}$ \\ ${ }^{1}$ Program Studi Biologi, Fakultas MIPA, Universitas Tanjungpura, \\ Jl. Prof. Dr. H. Hadari Nawawi, Pontianak, 78124 \\ Email korespondensi: ithapurnama70@gmail.com
}

\begin{abstract}
Ocimum basilicum is one type of vegetables that can be consumed without having to be processed. Food consumed must have high nutritional value, clean and free of microbes. Coliform is one of the bacteria that can cause disease in humans. This study aims to determine the value of MPN on samples Ocimum basilicum leaves from warung lamongan in Pontianak and determine the existence of coliform bacteria on Ocimum basilicum leaf samples from warung lamongan in Pontianak. Detection of coliform bacteria using the MPN method. Detection of $E$. coli was carried out using EMBA media. The results showed that all samples had interval values between $210 \mathrm{MPN} / \mathrm{g}$ to $>1100 \mathrm{MPN} / \mathrm{g}$. It showed that all samples excced the threshold determined by BPOM (2016), which was the maximum limit of coliform bacteria contamination in ready-toconsume vegetables was $<3 \mathrm{APM} / \mathrm{g}$. The results of the identification of the bacterial genus coliform group had the members of genera Escherichia and Citrobacter.
\end{abstract}

\section{Keywords: Ocimum basilicum, MPN, Escherichia, Citrobacter}

\section{PENDAHULUAN}

Sayur lalapan merupakan bagian tanaman seperti daun, batang, akar, bunga dan umbi yang dikonsumsi tanpa harus diolah. Salah satu jenis sayuran yang dijadikan lalapan yaitu kemangi. Kemangi memiliki kandungan gizi berupa protein, kalsium, fosfor, yang baik untuk kesehatan (Bahera et al, 2015). Menurut Pitojo, (1996) kemangi mempunyai khasiat untuk mengatasi bau mulut, bau badan, badan lesu, anti peradangan, antibiotik alami, diuretik, analgesik, melancarkan peredaran darah, membersihkan racun, antimalaria, nyeri haid, antijamur, mencegah kanker dan mengurangi kolesterol.

Makanan dan minuman yang dikonsumsi harus memiliki nilai gizi yang tinggi, bersih dan bebas dari komponen berbahaya atau organisme yang dapat menyebabkan keracunan atau menimbulkan penyakit (Marwanti, 2010). Mikroorganisme terutama bakteri dapat ditemukan di air, tanah, udara, mulut dan usus hewan termasuk manusia, serta tanaman, makanan maupun minuman (Adam \& Motarjemi, 2003). Bakteri dapat tumbuh dengan baik pada makanan yang mentah karena zat-zat gizi yang tersedia lebih baik (Supardi \& Sukamto, 1999).
Bakteri golongan Coliform merupakan salah satu sumber kontaminasi pada makanan dan minuman, serta dapat menyebabkan penyakit. Bakteri golongan Coliform yang terdapat pada makanan dan minuman menunjukkan adanya mikroba yang bersifat enteropatogenik yang berbahaya bagi kesehatan manusia (Suriawiria, 1985). Manfaat dari sayur lalapan tidak akan berguna apabila sayur lalapan tersebut mengandung mikroorganisme yang masuk ke dalam saluran pencernaan seperti bakteri golongan Coliform atau enteropatogenik. Oleh karena itu, perlu dilakukan pencegahan maupun pemeriksaan terhadap sayur lalapan, salah satunya pada daun kemangi.

Berdasarkan hasil penelitian yang dilakukan oleh Bunsal et al, (2015), keberadaan bakteri anggota spesies Escherichia coli pada daun kemangi (Ocimum sanctum L.) dan kol (Brassica oleraceae) sebagai menu ayam lalapan pada warung makan di Jalan Pierre Tendean Boulevard Kota Manado Tahun 2015, menunjukkan bahwa semua sampel kemangi mengandung bakteri anggota spesies E.coli dan sampel kol hanya 1 yang negatif, sedangkan 7 sampel lainnya positif terdapat bakteri anggota spesies E.coli yang melebihi ambang batas yang ditentukan BPOM (2016), yaitu batas maksimum cemaran bakteri golongan Coliform pada sayuran siap konsumsi yaitu <3 APM/ g. 
Mengingat rentannya kontaminasi bakteri pada lalapan, maka penting untuk diketahui adanya cemaran bakteri Coliform pada lalapan kemangi yang dijual di Kota Pontianak. Hal ini dikarenakan berdasarkan hasil pengamatan, kemangi yang dijadikan lalapan oleh pedagang makanan di Kota Pontianak umumnya tidak dimasak terlebih dahulu, dan hanya dicuci dengan air bersih yang juga tidak dimasak terlebih dahulu. Oleh karena itu, perlu dilakukan penelitian tentang keberadaan bakteri Coliform.

\section{BAHAN DAN METODE}

\section{Waktu dan Tempat Penelitian}

Penelitian dilaksanaan selama empat bulan, dimulai pada bulan Maret 2019 hingga Juli 2019, yang mencakup pengambilan sampel di lapangan, pengujian sampel dan analisis data. Pengambilan sampel daun kemangi dilakukan di 12 lokasi warung makan lamongan di Kota Pontianak. Pengujian sampel dilakukan di Laboratorium Mikrobiologi, Jurusan Biologi, Universitas Tanjungpura, Pontianak.

\section{Bahan}

Bahan yang digunakan dalam penelitian ini yaitu alkohol 70\%, akuades, larutan kristal violet (ungu), daun kemangi, Brilliant Green Lactose Broth Bile (BGLB), Buffered peptone water (BPW), Eosin Methylene Blue Agar (EMBA) dan Lactose Broth (LB).

\section{Prosedur kerja}

\section{Sterilisasi Alat}

Alat berupa cawan petri, gelas beaker, gelas erlenmeyer dan tabung reaksi dicuci bersih terlebih dahulu lalu dikeringkan, serta disterilisasi menggunakan autoklaf pada temperatur $121^{\circ} \mathrm{C}$ dan tekanan 2 atm selama 15 menit (Marlina, 2008).

\section{Pengambilan Sampel}

Pengambilan sampel dilakukan secara acak. Sampel diperoleh dari warung lamongan secara acak yang ada di enam Kecamatan di Kota Pontianak, meliputi Kecamatan Pontianak Barat, Kecamatan Pontianak Kota, Kecamatan Pontianak Selatan, Kecamatan Pontianak Tenggara, Kecamatan Pontianak Utara, Kecamatan Pontianak Timur. Total jumlah sampel yang diambil adalah sebanyak 12 sampel. Sampel dimasukkan ke dalam plastik, lalu dibawa ke laboratorium untuk dilakukan analisis.

\section{Pengujian bakteri Coliform menggunaan metode MPN (Most Probable Number)}

\section{a. Uji Penduga}

Sampel daun kemangi dipotong menjadi bagianbagian kecil, kemudian dihaluskan menggunakan blender. Sampel sebanyak 1 gram diambil dan dimasukkan ke dalam erlenmeyer yang berisi $9 \mathrm{ml}$ akuades sebagai suspensi, kemudian dihomogenkan menggunakan vortex. Sebanyak 1 gram sampel diambil dan dimasukkan ke dalam 9 $\mathrm{ml}$ akuades lalu digojok dengan menggunakan vortex sampai homogen hingga diperoleh pengenceran $10^{-1}$. Selanjutnya diambil $1 \mathrm{ml}$ pengenceran $10^{-1}$ dimasukan ke dalam tabung reaksi $10^{-2}$ yang telah berisi $9 \mathrm{ml}$ aquades, homogenkan menggunakan vortex. Selanjutnya diambil $1 \mathrm{ml}$ dari pengenceran $10^{-2}$ dimasukkan ke dalam tabung reaksi $10^{-3}$, kemudian dipipet masing-masing $1 \mathrm{ml}$ dari setiap pengenceran ke dalam untuk pengenceran tiga seri tabung yang berisi $9 \mathrm{ml}$ media LB. Selanjutnya semua pengenceran dalam media LB dimasukan ke dalam inkubator pada suhu $37^{\circ} \mathrm{C}$ selama $24-48$ jam (Fardiaz, 1993), dan diamati apabila hasilnya positif maka akan terbentuk gas pada tabung durham.

\section{b. Uji Penegas}

Uji Penegas dilakukan dengan cara mengambil 1 ose sampel yang positif atau yang terbentuk gas pada uji penduga dimasukan ke dalam masingmasing tabung yang berisi $4 \mathrm{ml}$ BGLB sesuai dengan tingkat pengenceran pada tabung uji pendahuluan, kemudian semua tabung reaksi dimasukan ke dalam inkubator pada suhu $37^{\circ} \mathrm{C}$ selama $2 \times 24$ jam. Uji penegas ditamdai dengan terbentuknya gas apabila hasilnya positif.

\section{c. Uji Pelengkap}

Suspensi sampel dari tabung yang menunjukkan hasil positif dalam uji konfirmasi selanjutnya diambil sebanyak 1 ose dan di inkubasi ke dalam cawan petri yang berisikan media Eosin Methylene Blue Agar (EMBA), kemudian diinkubasi di dalam inkubasi pada suhu $37^{\circ} \mathrm{C}$ selama $24-48$ jam. Koloni yang berwarna hijau metalik diduga merupakan koloni bakteri anggota genus Escherichia, dan koloni berwarna merah muda diduga merupakan koloni bakteri anggota genus Citrobacter. 


\section{HASIL DAN PEMBAHASAN}

\section{Hasil}

Pengujian Bakteri Coliform dengan Metode MPN pada Kemangi di Kota Pontianak

Hasil penelitian yang telah dilakukan menunjukkan bahwa nilai MPN bakteri Coliform pada daun kemangi di Kota Pontianak yaitu sampel dari Pontianak Kota 1100 (MPN/g), Pontianak Utara 460 (MPN/g), Pontianak Timur >1100 (MPN/g), Pontianak Tenggara 210 (MPN/g), Pontianak
Selatan >1100 (MPN/g), Pontianak Barat >1100 (MPN/g) (Tabel 1). Hal ini menunjukkan bahwa nilai MPN dari bakteri Coliform daun kemangi di Kota Pontianak melebihi ambang batas yang ditentukan BPOM (2016), yaitu batas maksimum cemaran bakteri golongan Coliform pada sayuran siap konsumsi yaitu <3 APM/g.

Tabel 1 Nilai angka paling mungkin (Most Probable Number) bakteri Coliform pada lalapan daun kemangi

$\begin{array}{cccc}\begin{array}{c}\text { Tempat pengambilan } \\ \text { sampel/ wilayah }\end{array} & \begin{array}{c}\text { Coliform } \\ (\mathrm{MPN} / \mathrm{g})\end{array} & \begin{array}{c}\text { Standar Coliform } \\ \text { Menurut BPOM (2016) }\end{array} & \text { Keterangan } \\ & & \end{array}$

$(\mathrm{MPN} / \mathrm{g})$

\begin{tabular}{cccc}
\hline Kota & 1100 & $<3$ & TMS \\
Utara & 460 & $<3$ & TMS \\
Timur & $>1100$ & $<3$ & TMS \\
Tenggara & 210 & $<3$ & TMS \\
Selatan & $>1100$ & $<3$ & TMS \\
Barat & $>1100$ & $<3$ & TMS \\
\hline
\end{tabular}

Keterangan: TMS (tidak memenuhi syarat)

Hasil isolasi dan karakterisasi bakteri Colifom

Berdasarkan hasil isolasi bakteri Coliform pada

kemangi di enam lokasi yaitu Pontianak Kota,

Pontianak Utara, Pontianak Timur, Pontianak
Barat, Pontianak Selatan dan Pontianak Tenggara diperoleh isolat dengan kode $\mathrm{K} 1, \mathrm{~K} 2, \mathrm{~K} 3, \mathrm{~K} 4$ (Tabel 2). Setiap isolat memilii karakeristik morfologi dan fisiologis yang berbeda (Tabel 2).

Tabel 2 Karakter morfologi dan isolat bakteri coliform pada sampel kemangi

\begin{tabular}{lllllll}
\hline Makroskopis & K1 & K2 & K3 & K4 & K5 & K6 \\
\hline Genus & Escherichia & & & & & \\
\hline Bentuk & Bulat & Bulat & Bulat & Bulat & Bulat & Bulat \\
Warna & Hijau & Hijau & Hijau & Hijau & Hijau & Hijau \\
& metalik & metalik & metalik & metalik & metalik & metalik \\
Tepian & Rata & Rata & Rata & Rata & Rata & Rata \\
Elevasi & Rata & Rata & Rata & Rata & Rata & Rata \\
\hline Genus & Citrobacter & & & & & \\
\hline Bentuk & Batang & Batang & Batang & Batang & Batang & Batang \\
Warna & Merah muda & Merah muda & Merah muda & Merah & Merah muda & Merah muda \\
& & & & muda & & \\
Tepian & Rata & Rata & Rata & Rata & Rata & Rata \\
Elevasi & Cembung & Cembung & Cembung & Cembung & Cembung & Cembung \\
\hline
\end{tabular}

\section{Pembahasan}

Pengujian bakteri Coliform dengan metode MPN, dilakukan melalui uji penduga dan uji penegas. Media yang digunakan dalam uji penduga adalah media Lactose Broth (LB). Media Lactose Broth (LB) mengandung laktosa yaitu sumber karbohidrat untuk bakteri melakukan fermentasi. Hasil positif ditandai dengan terbentuk gas, terbentuknya asam dilihat dari kekeruhan pada media dan gas yang dihasilkan dapat dilihat dalam tabung durham yang terdapat gelembung (Gambar 1). Media yang digunakan dalam uji penegas yaitu media Brilliant Green Lactose Broth Bile (BGLB). Media BGLB dapat menghambat pertumbuhan bakteri gram positif dan negatif selain Coliform. 

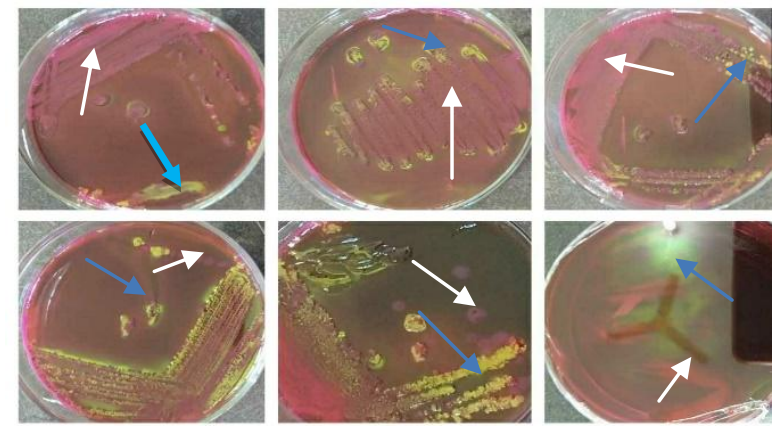

Gambar1. Deteksi Coliform di media EMBA dengan koloni bakteri berwarna hijau metalik Eschericia (panah biru) dan merah muda Citrobacter (panah putih)

Berdasarkan hasil dapat diketahui bahwa dari 12 sampel kemangi yang diuji semuanya tidak memenuhi syarat atau melebihi ambang batas yang ditentukan BPOM (2016), yaitu batas maksimum cemaran bakteri golongan Coliform pada sayuran siap konsumsi yaitu <3 MPN/g (Tabel 2). Sampel kemangi yang diperoleh dari Pontianak Kota 1100 (MPN/g), Pontianak Utara $460(\mathrm{MPN} / \mathrm{g})$, Pontianak Timur >1100 (MPN/g), Pontianak Tenggara 210 (MPN/g), Pontianak Selatan $>11 \times 10^{4} \quad(\mathrm{MPN} / \mathrm{g}), \quad$ Pontianak Barat $>1100$ (MPN/g) (Tabel 2). Hal ini menunjukkan bahwa sampel daun kemangi yang melebihi nilai MPN yang paling tinggi yaitu $>1100$ berasal dari lokasi penjualan di Pontianak Timur, Pontianak Selatan dan Pontianak Barat, sedangkan sampel daun kemangi yang memiliki nilai MPN paling rendah berasal dari lokasi pedagang di Pontianak Tenggara.

Tingginya nilai MPN menunjukkan banyaknya bakteri dalam suatu sampel. Banyaknya jumlah bakteri pada sampel kemangi diduga dapat dipengaruhi oleh tempat penyimpanan sampel atau wadah, air yang digunakan, kondisi lingkungan yang tidak higienis dan lokasi penjual di tepi jalan dapat mempengaruhi kontaminasi bakteri. Berdasarkan hasil observasi dari keenam pedagang ditemukan dua meggunakan wadah yang tertutup dan kantong plastik sehingga mengurangi terjadi kontaminasi secara langsung, sedangkan empat dari enam sampel yang lainnya menggunakan wadah yang terbuka sehinga mudah terkonaminasi mikroba dari lingkungan sekitar. Menurut Rahmadhani \& Sumarmi (2017) penggunaan wadah seharusnya tertutup saat penyajian makanan yang bertujuan untuk menghindarkan makanan dari kontaminasi udara maupun vektor yang biasa terdapat di sekitar makanan seperti lalat. Makanan yang disajikan harus ditempatkan di tempat yang bersih agar sirkulasi udara yang berlangsung juga bersih dan terbebas dari cemaran bakteri yang terbawa dari udara yang kotor. Hal ini didukung oleh pernyataan Susanna et al, (2010) yaitu kontaminasi $E$. coli juga banyak ditemukan pada makanan yang disajikan tanpa tutup.

Berdasarkan hasil pengamatan air yang digunakan untuk mencuci kemangi oleh pedagang yaitu air yang tidak di masak terlebih dahulu dan di tampung dalam ember. Tahap pencucian sayuran mentah dengan menggunakan air mengalir merupakan salah satu cara untuk meminimalisir kontaminasi. Proses pencucian ini sesuai dengan teori Afrianto (2008) bahwa pencucian bahan baku sebaiknya dilakukan di bawah air yang mengalir sehingga kotoran langsung terbuang. Bahaya yang mungkin dapat muncul pada saat proses penyiangan dan pencucian ini dapat terjadinya kontaminasi dan pertumbuhan mikroba Colifom. Menurut supardi dan sukamto (1999) mikroba khususnya bakteri dapat tumbuh lebih baik pada bahan pangan mentah karena zat-zat gizi yang tesedia lebih baik. Semakin tinggi tingkat kontaminasi bakteri Coliform semakin tinggi pula risiko kehadiran bakteri patogen lain, sebaliknya, semakin sedikit kandungan bakteri Coliform maka baik bakteriologis air minum tersebut (Natalia et al., 2014).

Keberadaan bakteri anggota spesies E.coli pada sampel diduga berasal dari air yang digunakan oleh produsen kurang higienis karena air yang digunakan tidak dimasak. Berdasarkan hasil obsevasi dari enam pedagang, air yang digunakan mencuci kemangi menggunakan air mentah. Hal ini sesuai dengan pernyataan Indriani (2004) yang menyatakan jika air yang sudah terkontaminasi bakteri Coliform berada di lingkungan yang memungkinkan akan terus tumbuh.

Berdasarkan hasil deteksi genus Coliform menggunakan media Eosin Methylene Blue Agar (EMBA) diperoleh koloni warna hijau metalik (dengan kilap logam) yang menandakan keberadaan bakteri anggota genus Escherichia. Hal ini sesuai dengan pendapat Jorgensen 2015 koloni yang tumbuh berinti gelap disertai kilap logam pada permukaan Eosin Methylen Blue Agar (EMBA) merupakan ciri koloni anggota spesies Escherichia coli. Selain warna hijau metalik deteksi genus Coliform menggunakan media Eosin Methylene Blue Agar (EMBA) diperoleh koloni warna merah muda yang diduga bakteri anggota genus Citrobacter. Adanya warna merah muda 
keunguan menandakan bahwa semua sampel yang diinkubasi pada media EMBA tidak tumbuh E.coli melainkan menandakan adanya keberadaan Coliform lain. Cappuccino \& Sherman (2002), bahwa setelah diinkubasi koloni yang tumbuh pada medium Eosine Methylene Blue Agar (EMBA) berwarna merah atau merah muda berarti air sampel mengandung bakteri Citrobacter yang merupakan Coliform non fekal. Hal ini di dukung oleh pernyataan Fardiaz (1993), pada media EMBA, koloni Coliform non fekal mempunyai diameter yang lebih besar (1.0-3.0 mm) berwarna merah muda dan bagian tengahnya berwarna gelap seperti mata ikan. Bakteri ini sering ditemukan terkontaminasi pada sayuran segar (Stevens et al., 2003; Falomir, et al 2010). Menurut Bintari et al., (2015) keberaaan bakteri anggota genus Citrobacter pada sampel umbi wortel yang menyebabkan penyakit busuk lunak. Hal ini di dukung oleh pernyataan oleh Joko et al, (2013) dalam Bintari et al, (2015) beberapa bakteri seperti anggota genus Citrobacter, Pectobacterium, Enterobacter, Klebsiella dan Pseudomonas yang dapat menimbulkan gejala penyakit busuk lunak setelah diinokulasikan pada tanaman anggrek (Phalaenopsis sp.). Kemampuan bakteri anggota genus Citrobacter yang dapat mendegradasi dinding sel tanaman sehingga dapat menyebabkan busuk lunak.

Produk pangan segar sayur dan buah segar siap santap rentan terhadap kontaminasi mikroba. Produk-produk segar ini berada pada urutan kedua jenis produk yang paling rentan terhadap kontaminasi setelah produk seafood (Sizer \& whitey 2007). Proses yang dimulai dari panen hingga penanganan produk akhir memungkinkan sayur dan buah segar untuk terkontaminasi oleh bakteri patogen. Proses minimal pada produk buah dan sayur segar menyebabkan produk menjadi berisiko karena bagian sel pelindung alami dari buah dan sayur telah dihilangkan saat proses pemotongan atau pengupasan.

Mikroorganisme yang mungkin mengkontaminasi produk buah dan sayur segar yang diproses minimal adalah bakteri pembentuk spora, bakteri non pembentuk spora, virus, dan parasit. Beberapa studi hasil fakta kasus keracunan sayur dan buah segar yang terjadi menunjukkan mayoritas kontaminasi berasal dari bakteri non pembentuk spora (55\%), seperti Salmonella dan E. coli (James \& Swain 2008). Keberadaan bakteri Coliform menunjukkan adanya kontaminasi air yang selanjutnya ikut mengkontaminasi produk sayur dan buah. Kontaminasi air pada sayur dan buah dapat berasal dari air irigasi selama proses panen, tanah tempat pertumbuhan, pupuk yang digunakan, maupun berasal dari air yang digunakan untuk pencucian (Yani et al., 2016).

\section{DAFTAR PUSTAKA}

Adams, M \& Motarjemi, Y, 2003, Dasar-dasar Keamanan Makanan Untuk Petugas Kesehatan, Buku Kedokteran EGC, Jakarta

Afrianto, E, .2008, Pengawasan Mutu Bahan atau Produk Pangan Jilid 1. Direktorat Pembinaan Sekolah Menengah Kejuruan, Jakarta

Agusta, Andria, 2000, Minyak Atsiri Tumbuhan Tropika Indonesia, ITB Press, Bandung

Arnia \& efrida, w, 2010, Identifikasi kontaminasi bakteri pada daging sapi segar yang dijual di pasar kota bandar lampung, Journal Medical of Lampung University, ISSN 2337-3776, : 43-50

Andrian, GB, Fatimawati \& Novel, SK, 2014, Analisis cemaran bakteri Coliform dan identifikasi Escherichia coli pada air isi ulang dari depot di

kota manado, Jurnal Ilmiah Farmasi-Unsrat, 3 (3) : 2302-2493

Badan Pengawas Obat dan Makanan, 2016, Laporan Tahunan 2016 Badan Pengawas Obat dan Makanan Badan POM RI, Jakarta

Baliwati, Y.F. 2004, Pengantar Pangan dan Gizi, Penebar Swadaya, Jakarta.

Batt, C. A, 2014, Encyclopedia of food microbiology, Academic Press, London

Balia, RL, Chairunnisa, Rachmawan O \& Wulandari E, 2011, Derajat keasaman dam karakteristik organoleptik produk fermentasi susu kambing dengan penambahan sari kurma yang diinokulasikan berbagai kombinasi starter bakteri asam laktat, Jurnal Ilmu Ternak, 11 (1) : 49-52

Behera, B., Biswal, D., Uvanesh, K., Srivastava, A.K., Bhattacharya, M.K., Paramanik, K., 2015, Modulating the properties of sunflower oil based novel emulgelsusing castor oil fatty acid ester: Prospects for topical antimicrobialdrug delivery, Colloids and Surfaces B: Biointerfaces, 155- 164

Bintari, N,W,D , Retno Kawuri, Meitini Wahyuni \& 2015, Isolasi Dan Identifikasi Bakteri Penyebab Busuk Lunak Pada Umbi Wortel (Daucus carota L.) Varietas Lokal di Bali, Jurnal Metamorfosa, 2 (1) : 9-15 
Bunsal, TB, Joseph, WBS \& Rattu, 2015, 'Keberadaan Escherichia Coli Pada Kemangi (Ocimum Sanctum L.) Dan Kol (Brassica Oleraceae) Sebagai Menu Ayam Lalapan Pada Warung Makan Di Jalan Piere Tendean Boulevard Kota Manado, Fakultas Kesehatan Masyarakat

Cappuccino, J.G \& Sherman, N, 2005, Microbiology A Laboratory Manual 7 edition, Person Education, Inc, San Fransisko

Cappuccino, J.G \& Sherman, N, 2002, Microbiology a Laboratory Manual, The Benjamin/Cumming Publishing Company, Inc. Menlo Park, California

Departemen Kesehatan RI, 2003, Keputusan menteri kesehatan RI tentang persyaratan hygiene sanitasi jasa boga, Depkes RI, Jakarta

Fardiaz, S, 1989, Mirobiologi Pangan 1, Penerbit PT Gramedia Pustaka Utama, Jakarta

Fardiaz, S., 1993, Analisis Mikrobiologi Pangan, Raja Grafindo Persada, Jakarta

Falomir, M.P., D, Gozalbo \& H. Rico, 2010, Coliform Bacteria in Fresh Vegetables: From Cultivated Lands to Consumers, formatex, 2, 1175-1181

Indriani, DM, 2004, Kandungan bakteri coliform dalam es batu ada pedagang kaki lima di jalan kalimanta kecamatan sumbesari jember, fakultas kesehatan masyarakat, Universitas Jember

Jawetz, Melnick \& Adelberg's, 2005, mikrobiologi kedokteran, Selembe medika, Jakarta

James, J., Baker, C., \& Swain, H., 2008, Prinsip-prinsip Sains untuk, Erlangga, Jakarta

Jorgensen, J.H., \& Ferraro, M.J., 2009, Antimicrobial Susceptibility Testing: A Review of General Principles and Contemporary Practices, Medical Microbiology, 49 : ISSN 1750

Joko, T., A. Subandi, N. Kusumandari, A. Wibowo \& A. Priyatmojo, 2013, Activities of Plant Cell Wall-degrading Enzymes by Bacterial Soft Rot of Orchid. Achives of Phytopathology and Plant Protection. Taylor \& Francis, Cited: 17.4.2014

Knechtges, P,L., 2011, Food Safety Theory and Practice, East Carolina University

Marlina, 2008, Identifikasi Bakteri Vibrio parahaemolitycus dengan Metode Biologi dan Deteksi Gen toxRnya secara PCR, Jurnal Sains dan Teknologi Farmasi, 13 (1) :11-17
Marwanti, 2010, Keamanan pangan dan penyelenggaraan makanan, Yogyakarta

Massimo F. 2004. Composition and properties of Indonesian palm civet coffee (kopi luwak) and Ethiopian civet coffee. Food Reearch International, 37 : 901-912

Nazaruddin., 1999, Sayuran Dataran Rendah. Penebar Swadaya, Jakarta

Natalia LA, Bintari SH \& Mustikaningtyas D, 2014, Kajian kualitas bakteriologis air minum isi ulang di kabupaten blora. Unnes Journal of Life Science, 3 (1) :31-38

Pitojo. S, 1996, Kemangi dan Selasih, Trubus Agriwidya, Semarang

Rahmadhani, D. \& Sumarmi, S., 2017, Gambaran Penerapan Prinsip Higiene Sanitasi Makanan Di PT Aerofood Indonesia, Tangerang, Banten. Amerta Nutr, 1 (291)

Stevens, M., N. Ashbolt \& D. Cunliffe. 2003. Review of Coliform: as Microbial Indicators of Drinking Water Quality, Australian Government, National Health and Medical Research Council, Australia

Sizer \& Whitney, 2007, Nutrition: Concepts and Controversies, Thomson Wadsworth, AS

Suriawiria, 1985, Pengantar mikrobiologi umum, Angkasa, Bandung

Suriaman. E, \& Juwita, Uji kualitas air, Fakultas sainsdan teknologi, universitas islam negeri, Malang

Supardi, \& Sukamto. 1999. Mikrobiologi Dalam Pengolahan Dan Keamanan Produk Pangan, Penerbit Alumni, Bandung

Sutarno, H. \& Atmowidjojo. 2001. Tantangan Pengembangan dan Fakta Jenis Tanaman Rempah, Prosea Indonesia-Yayasan Prosea, Bogor

Susanna, D., Indrawani M, Y. \& Zakianis, 2010, Kontaminasi Bakteri Escherichia coli pada Makanan Pedagang Kaki Lima di Sepanjang Jalan Margonda Depok, Jawa Barat, Kesehatan masyarakat, $5: 110-115$

Tamaroh S., 2003. Knowledge, Practices and Attitude on Food safety of Food handlers in Catering Establishmen in Yogjakarta, Seminar Nasional PAPTI 30 - 31 Juli 2002, Malang 
Protobiont (2019) Vol. 8 (3) : $34-40$

Yunita \& Dwipayanti, 2010, Kualitas Mikrobiologi Nasi Jingo Berdasarkan Angka Lempeng Total, Coliform Total dan Kandungan Escherichia coli, jurnal biologi , 16 (1) : 15-19

Yani, A.V., Hasbi, Priyanto, G \& Pambayun, R., Wijaya, A., 2006, Tingkat Kontaminasi Mikroba dan Residu Pestisida pada Sayuran Segar, Proceeding National Seminar of Suboptimal Area, Palembang

Waluyo \& Lud, 2009, Teknik dan metode dasar dalam mikrobiologi, Universitas Muhammadiyah Malang Press, Malang

Waluyo \& Lud, 2009, Mikrobilogi Lingkungan, Universitas Muhammadiyah Malang Press, Malang 